\title{
Correction to: Decision-Making in Management: Methods and Behavioral Tools
}

Kesra Nermend, Małgorzata Latuszyńska, and Eleftherios Thalassinos

\section{Correction to:}

K. Nermend et al. (eds.), Decision-Making in Management, Contributions to Management Science, https://doi.org/10.1007/978-3-030-67020-7

Book editor's name was inadvertently published incorrectly in the online version. This has now been corrected through out the book as Eleftherios Thalassinos.

\footnotetext{
The updated version of these chapters can be found at:

https://doi.org/10.1007/978-3-030-67020-7

https://doi.org/10.1007/978-3-030-67020-7_4

https://doi.org/10.1007/978-3-030-67020-7_18
} 